\title{
1. The foundations for an ecological economy: an overview
}

\section{Joshua Farley}

\subsection{INTRODUCTION}

This book began as a single-volume Festschrift to honor the work of Herman Daly, one of the pioneers of ecological economics. Unfortunately, the destiny of too many Festschrifts is to sit on the shelf unread, and we believe that among all economists, Daly's ideas are the most important to disseminate and apply. Furthermore, given the significance of Daly's contributions and the numerous scholars he has influenced, a single volume would be inadequate. We have therefore chosen to publish two volumes in different formats: one volume available in print or as an ebook with Edward Elgar Publishing and the other an online, open-access ebook downloadable at http://www.uvm.edu/ jfarley/BUG.

Daly came of age as an economist during the 1960s, a time of increasing alarm over the ecological impacts of economic growth, population growth and global inequality. Mainstream economists as a whole were largely complacent about these issues, trusting in technology and substitution to address resource limits (Barnett and Morse, 1963; Simpson et al., 2005) and in markets to distribute wealth in proportion to an individual's role in creating it (Clark, 1908). Continuous economic growth would provide the resources to protect the environment and eliminate poverty and incentives to have fewer children, stabilizing the global population (see Daly, 1977 for a detailed discussion).

Daly, in contrast, had the crucial insight that the human economy is a subsystem sustained and contained by a delicately balanced global ecosphere, which in turn is fueled by finite flows of solar energy. As the economy expands, it transforms more ecosystem structure into economic products and generates greater flows of waste, both of which reduce the capacity of ecosystems to generate life sustaining ecosystem services and other amenities. He realized that ever-increasing material consumption must have devastating impacts on natural systems and the non-market benefits they generate and was therefore neither socially desirable nor 
biophysically possible. Economic analysis must begin with the recognition that the economy is wholly dependent on the finite global ecosystem. Furthermore, given finite resources, their just distribution within and between generations is an unavoidable focus of economic analysis. As early as the late 1960s, he began calling for a steady-state, no-growth economy with a more equal distribution of wealth and income (Daly, 1968, 1973). For a brief period in the 1960s and 1970s, it almost seemed that Daly's view might win out on the policy level. The United States and other developing nations passed major legislation to protect the environment and to improve the distribution of wealth.

Unfortunately, since then global environmental problems have grown significantly worse, income inequality has skyrocketed and the global population pushes toward ten billion. In the world's richest country, the United States, the poverty rate has actually increased. Paradoxically, despite a doubling in per capita income since the 1960s, there seems to be a growing belief that we can no longer afford to tackle environmental problems and inequality.

Herman has nonetheless continued to dedicate his professional life to creating the transdisciplinary field of ecological economics that seeks to balance what is biophysically possible with what is socially, ethically and psychologically desirable. We believe that the best tribute to Herman is to help advance this agenda before it is too late. The goal of these books is therefore to build on Herman's work to propose sustainable, just and efficient solutions to society's most pressing ecological and economic problems. The goal of this chapter is to briefly describe the problems we face, explain why the current economic system is failing to address them and suggest how Daly's work is capable of transforming our complex ecological economic system. The chapter concludes with a brief introduction to the remaining chapters in this book and its companion volume, all contributed by scholars and activists working toward the creation of a sustainable and desirable economy.

\subsection{ENVIRONMENTAL PROBLEMS AND THE ANTHROPOCENE}

Geologists divide geologic time into epochs, which correspond to dramatic changes in biophysical events on our planet. Our current official epoch, the Holocene, has been characterized by an unusually stable climate that has provided conditions conducive to the development of agriculture. Agriculture in turn allowed the population density, accumulation of surplus production and division of labor that were essential to developing civilization. 
Human society is profoundly influenced by environmental conditions. Homo sapiens first appeared about 200000 years ago during a period of dramatic climate instability that persisted for the first 95 percent of human history. In spite of climate instability, small bands of humans characterized by remarkably similar stone-age technologies and highly egalitarian political and economic systems nonetheless managed to spread across the planet. When the Holocene arrived around 11700 years ago, many of these spatially-separated groups responded to a newly stable climate in remarkably similar ways. For example, although the North American populations were completely isolated from the old world, when the Europeans 'discovered' the major American civilizations in the sixteenth century, they found large cities, agricultural systems and hierarchical political, economic and religious institutions that were instantly recognizable, though none of these institutions had evolved in the many millennia preceding the Holocene (Richerson et al., 2001).

Humanity is again facing dramatic environmental changes, but this time as a result of our own actions. Though climate change is the most widely discussed, biodiversity loss, nitrogen and phosphorous cycles, ocean acidification, land use change, freshwater use, ozone depletion, chemical pollution and atmospheric aerosol loading also threaten unacceptable environmental change that may be incompatible with continued human development or even survival (Rockstrom et al., 2009). In fact, the human influence on the environment is now so profound that many scientists argue that we have entered a new geologic epoch, the Anthropocene: human impacts on the environment are now on the scale of geological forces (Crutzen, 2002). There is considerable debate over when the Anthropocene actually began, but one powerful contender is the start of the Industrial Revolution, when the vast power of fossil fuels (and their immense waste emissions) was first unleashed. Not coincidentally, the origins of both the modern market economy and the theory describing it both date to this same era. There is little debate that a Great Acceleration in human activities and their environmental impacts began around 1950. Among other radical changes, the human population and species extinctions doubled in only 50 years, fossil fuel use and water use more than tripled, fertilizer use increased five fold and the size of the economy (as measured by gross domestic product (GDP)) increased 15 fold (Steffen et al., 2011).

The impacts of the Anthropocene on human development may be at least as profound as those of the Holocene, but with potentially devastating consequences. Humans, like all species, depend on well-functioning ecosystems for their survival, and human civilization almost certainly depends on agriculture. Unfortunately, agriculture may be the greatest single threat to global ecosystems (Brown, 2012; Godfray et al., 2010; 
Tilman et al., 2011). Our global economy also depends on fossil fuels, which provide 86 percent of our energy supply, and fossil fuel emissions vie with agriculture as the dominant threat to global ecosystems. Critical economic and ecological thresholds are in direct conflict. Society must thread a narrow path between ecological and economic collapse.

Growing inequality only exacerbates the problems of ecological degradation. The Great Acceleration initially coincided with the Great Compression: a period during which wages, incomes and the distribution of wealth became dramatically more equal, largely as a result of government policies influenced by the Great Depression and Keynesian economics. Economic inequality in the United States reached a minimum during the early 1970s, but has since increased nationally and globally to record levels in what is known as the Great Divergence (Alvaredo et al., 2013; Piketty and Saez, 2006).

A brief look at our most important economic sector - agriculture can help illustrate the severity of the challenges we currently face. Most economists would agree that there are rising marginal costs to economic production, and diminishing marginal benefits. The goal of economists is generally to maximize net benefits, which occur when marginal costs (which translate into a supply curve in market economics) are equal to marginal benefits (the demand curve).

The supply curve should include not only the marginal costs of labor, capital and material inputs, but also those of ecological degradation. Recent studies suggest that agricultural impacts already threaten or exceed ecological thresholds (Foley et al., 2011; IPCC, 2013; Millennium Ecosystem Assessment, 2005; Reid et al., 2010; Rockstrom et al., 2009; Steffen et al., 2011) beyond which the marginal costs of continued activity become immeasurably high. Thresholds represent the limits of marginal analysis: a marginal change in supply leads to non-marginal change in costs. To paraphrase Herman Daly, at a threshold, one marginal step takes us over the precipice (Daly, 1977). It's reasonable to assume that the supply curve for conventional agriculture becomes increasingly vertical as it approaches one of these thresholds. ${ }^{1}$

The demand curve is determined by marginal benefits. Humans confront a physiological threshold when they fail to consume enough food to survive, at which point the physiological demand curve for food becomes vertical. Once we have met our basic survival needs, the marginal benefits from food fall dramatically. Arguably, for the one billion malnourished people on the planet who may suffer retarded development, high mortality rates and so on, the marginal benefits from additional nutrition are immeasurably high already.

The demand curve described here is quite different from market 


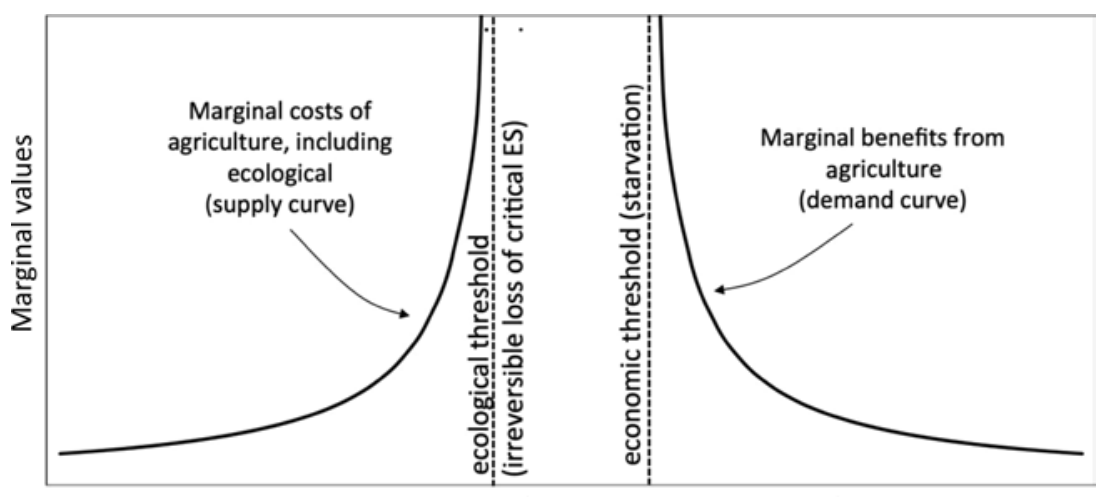

Food production (conventional agriculture)

Figure 1.1 Conceptual supply and demand curves for food production that account for ecological costs and the preferences of the poor, assuming current technologies and economic institutions

demand, which weights preferences by purchasing power. Global agriculture produces enough to feed the world, but an unequal distribution of purchasing power results in a highly unequal distribution of food. During the food crisis of 2007-08, when drought, increased ethanol production and speculation led the price of staple grains to double, the richest countries with the highest levels of per capita food consumption saw negligible change in demand or in the percentage of food being thrown away. Poor countries, in contrast, saw a significant increase in malnutrition, social disruption and political turmoil. When income is highly unequal, markets may allocate essential resources to those who gain the least marginal benefit (Farley et al., 2015).

Figure 1.1 depicts supply and demand curves based on these assumptions concerning marginal costs and benefits. With current production practices, economic institutions and human populations, the supply and demand curves do not intersect, and we are forced to choose between unacceptably high ecological or social costs. Ecological catastrophe of course will also lead to unacceptable social costs. We require agricultural systems that reduce ecological impacts while producing adequate food, as well as a much better distribution of the food we do produce. We require economic institutions that incentivize those agricultural systems and distribute food more equitably.

This economic (but non-market) analysis of supply and demand for food systems applies to the supply and demand of other essential resources and to the economy as a whole. For example, greenhouse gas emissions 
currently exceed absorption capacity, threatening runaway climate change in the future. If we immediately reduce emissions to sustainable levels, the resulting economic disruption could prove catastrophic. Aggregate economic activity already exceeds ecological thresholds, while in our current system failure to keep growing leads to unemployment, poverty and misery. We need a new economic system capable of addressing these ecological and physiological thresholds before the former become irreversible and catastrophic, and the latter result in social or economic collapse. Herman Daly's economic theories can help create this system.

\subsection{THE RESPONSE OF MAINSTREAM ECONOMICS $^{2}$}

While some mainstream economists are responding to the dual challenges of the Great Acceleration and the Great Divergence, the evolution of the discipline as a whole has likely exacerbated these trends. The Great Acceleration began around the time that mainstream economics became obsessed with economic growth. Prior to 1947, the phrase 'economic growth' appeared just once in all the economic journal articles indexed in Econlit, while in the decade of the 1950s it appeared 178 times, and has shown exponential increase since then.

Concerns over biophysical constraints to growth surfaced in the 1940s and 1950s (The President's Materials Policy Commission, 1952), but among economists and policy makers, largely gave way in the 1960s to faith in technological progress and endless substitutability (Barnett and Morse, 1963; Milliman, 1962; Spengler, 1961). The advent of Earth Day, petroleum price shocks and the publication of numerous environmental critiques of growth in the early 1970s reignited concerns over biophysical constraints. Economists initially reacted to these concerns with condescension and hostility, referring, for example, to Limits to Growth (Meadows et al., 1972) as 'such a brazen, impudent piece of nonsense that nobody could possibly take it seriously' (Beckerman, 1972, p. 327); one of the 'doomsday models' that are 'bad science and therefore bad guides to public policy' (Solow, 1973, p. 43); 'an empty and misleading work ... less than pseudoscience and little more than polemic fiction' (Passell et al., 1972, p. 1); and an example of crying wolf (Kaysen, 1972; all cited in Yissar, 2013). In spite of these vicious criticisms, economists began responding to concerns over resource depletion in sufficient numbers to form the sub-discipline of natural resource economics, which focused on the optimal use of raw materials and fossil fuels, considered obligations to future generations and integrated natural resources into economic growth models. Nonetheless, 
most economists continued to assume that capital, labor and technology were near perfect substitutes for natural resources (Dasgupta and Heal, 1979; Hartwick, 1977; Nordhaus et al., 1973; Solow, 1974a, 1974b, 1997; Stiglitz, 1974, 1997), rather than complements to resources, as Daly and others argued (Daly, 1997). Resource scarcity would not limit growth.

Economists also began to consider environmental amenities (aka ecosystem services) and pollution (Ayres and Kneese, 1969; Krutilla, 1967; Smith and Krutilla, 1979) - common property whose values are often ignored by market decisions - giving rise to the sub-discipline of environmental economics. Environmental economists generally accepted limitless substitution for natural resources, though not necessarily for benefits provided by unique ecosystems. However, the general conclusion is that if appropriate policies such as environmental taxes, cap and trade systems and economic incentives for providing or protecting ecosystem services internalize these failures into market prices, growth can continue unabated (Simpson et al., 2005).

The emergence of natural resource and environmental economics is certainly promising, and these sub-disciplines favor some of the same policies as ecological economics. Nonetheless, the reaction of mainstream economics to the Great Acceleration falls short for two reasons. One problem lies within these sub-disciplines, which continue to view the planetary ecosystem as the part and the economy as the whole, as epitomized by the definition of environmental problems as externalities that can be internalized into economic decisions. Efficient allocation is assumed to generate sustainable outcomes, and just distribution is rarely addressed. Endless economic growth remains the goal. Ecological economists, in contrast, believe that the nature of the economy as a physical subsystem of a finite planet makes continuous exponential growth impossible. Irreducible uncertainty concerning ecological impacts means that future costs are unknowable. Ecological sustainability and just distribution must take precedence over efficient allocation. Other important differences between these neoclassical sub-disciplines and ecological economics are nicely summarized elsewhere (Daly, 2007; van den Bergh, 2001), and therefore need not be reviewed here.

The second major problem is that natural resource and environmental economics have had little impact on mainstream economics as a whole. One prominent economist states that '[n]ature did not appear much in twentieth century economics, and it doesn't do so in current economic modelling. When asked, economists acknowledge nature's existence, but most deny that she is worth much' (Dasgupta, 2008, p. 1). Another argues that while 'there is a branch of growth theory that includes environmental and resource variables ... this has not affected the core of growth theory and associated policy debate. Moreover, most growth models with 
resources exclude realistic constraints on the substitution possibilities between energy and capital' (Ayres et al., 2013, p. 80). In short, natural resource, environmental and ecological economics all 'remain somewhat isolated from the main body of contemporary economics, especially as the discipline is presented in textbooks and journals' (Dasgupta, 2008, p. 2).

The Great Divergence in turn coincides with the period during which standard economics largely abandoned any concern over the distribution of wealth. Previously, many economists recognized that diminishing marginal utility implied that a more equal distribution of wealth increased total utility, all else equal (for example, Marshall, 1890). In the 1970s, however, mainstream economics solidified its position that since it was impossible to compare utility between individuals, economists should focus on the supposedly value-neutral goal of satisfying subjective preferences (for example, Stigler and Becker, 1977), typically failing to explicitly acknowledge that markets weight preferences by purchasing power. Essential needs were treated the same as 'tastes.' The result was the use of 'wealth rather than happiness as the criterion for an efficient allocation of resources' (Posner, 1985, p. 88). Redistribution may reduce incentives to accumulate wealth, and equality and efficiency are in conflict (Okun, 1975). It is not unusual for conventional economists to acknowledge that '[w]e live in a world of staggering and unprecedented income inequality' but to then assert that ' $[\mathrm{o}] \mathrm{f}$ the tendencies that are harmful to sound economics, the most seductive and ... the most poisonous, is to focus on questions of distribution' (Lucas, 2004). From this perspective, it was perfectly efficient and utility-maximizing for those consuming the least amount of food to reduce consumption by the most during the 2007-08 food crisis, since they were 'unwilling' to pay as much for food as the rich.

In recent years it has become increasingly common for influential economists to acknowledge that growing inequality is a serious problem (for example, Piketty, 2014; Piketty and Saez, 2006; Stiglitz, 2014, see also Paul Krugman's weekly column in the New York Times). However, within the mainstream, the importance of distribution is obscured by the economist's obsession with efficiency, as economists define it. Few, if any, mainstream economists question the efficiency of market allocation, regardless of income distribution or the essential nature of a particular resource. Few, if any, challenge the assumption that allocating resources according to preferences weighted by purchasing is optimal, or ask if the world's poor would offer a different definition of optimality.

Mainstream economists therefore have an entirely different interpretation of supply and demand than was presented in Figure 1.1. If belief in technological progress and the capacity for substitution is virtually unlimited, marginal costs will never become immeasurably large. For example, 
the influential Stern Review on the economics of climate change (Stern, 2006) assumes that even if we do nothing to mitigate climate change, continued economic growth ensures that future generations will be better off than the present. Marginal benefits for food cannot become immeasurably high because the destitute essentially drop off the demand curve when the price of staple grains exceeds their capacity to pay.

In distinct contrast, Herman Daly and his supporters argue that economic theory must acknowledge that the economy is entirely dependent on the raw materials, energy flows and ecosystem services that nature provides. Furthermore, we cannot solve ecological problems without simultaneously pursuing a just distribution of wealth and resources: in a world of pronounced income inequality, addressing the conflict between food production and ecosystem services by internalizing the costs of ecological degradation into market prices would result in severe hardships for the poor, and, at most, mild inconvenience for the rich. The decision to prioritize the preferences of the rich and the current generation is purely normative. We urgently require an economic system that prioritizes ecological sustainability, just distribution and obligations to future generations while acknowledging the profound uncertainty inherent to complex systems. Herman Daly and the scientists in these volumes are actively working to develop economic theories that support this transition. They recognize that climate change, resource depletion, population growth, the unjust distribution of resources and the current financial crisis are all interrelated components of a single complex system. We turn now to the challenge of changing complex systems.

\subsection{EFFECTING CHANGE IN COMPLEX SYSTEMS}

After decades of study using computer models and empirical evidence, Donella Meadows came up with a series of leverage points that are particularly effective at changing complex systems (Meadows, 2009). By conscious design or intuition, Daly's work concentrates on three of the most powerful of these levers: changing the paradigm; changing the goals; and changing the rules.

A paradigm is the worldview underlying the theory and methods of a field or discipline. Herman has changed the conventional economic paradigms concerning biophysical possibility and human behavior. In regards to biophysical possibility, Daly rejects analysis of the economic system as the whole, capable of expansion without limit, and the ecosystem as a part that supplies useful raw materials and services. Instead, Daly argues that economic analysis must begin with the recognition that the economic 
system is sustained and contained by the finite global ecosystem, which supplies all raw materials required for economic production, absorbs all resulting waste flows and provides irreplaceable ecosystem services essential to our survival (Daly, 1973, 1991). Energy is an essential input into all economic production. We have finite stocks of terrestrial energy sources, finite flows of solar energy and useful energy is always lost in the economic process. The raw materials that the economy transforms into economic goods and services alternatively serve as the structural building blocks of ecosystems. Arranged in particular configurations, these materials create ecosystem funds capable of transforming solar energy into a flux of ecosystem services essential to the survival of humans and all other species (Malghan, 2011). Resource extraction and waste emissions significantly alter these configurations, threatening the essential and non-substitutable services they generate, including the reproduction of renewable resources. Continuous physical growth of the economy is therefore impossible within a larger, non-growing, biophysical system (Daly, 1996).

Daly has also challenged the ruling paradigm concerning human behavior. Conventional economists model people as perfectly rational, self-interested and insatiable individuals who gain utility only from consumption, not from interaction with others, except as that contributes to consumption. Daly, in contrast, rightfully insists that we are persons-incommunity who define ourselves more by our relationships and associations with other individuals and groups than by the stuff we own. If you take away these relationships, there is little left of the individual (Daly and Cobb, 1994). Within mainstream economics, the sub-discipline of behavioral economics also challenges conventional assumptions of human behavior, but so far has had little impact on the discipline's core assumptions as presented in introductory textbooks. In fact, simply studying economics makes people more likely to conform to conventional assumptions (Cipriani et al., 2009; Kirchgässner, 2005).

Daly argues that acknowledgement of biophysical limits and our nature as persons in community forces us to change the goals of economic activity. Conventional economists prioritize efficient allocation, defined as any allocation in which it is impossible to make one person better off without making someone else worse off, and claim that free markets achieve this goal. Efficient allocation boils down to the maximization of monetary value subject to the initial distribution of wealth and resources, hence economists pursue the dynamic goal of ever-increasing GDP. ${ }^{3}$ Daly offers instead three alternative economic goals: ecological sustainability; just distribution; and efficient allocation (Daly, 1992). Humanity depends for its survival on the life support functions of the planetary ecosystem. If we show any moral concern for future generations, and the current generation 
as a whole is not destitute, ecological sustainability is essential. The goal of sustainability limits the total amount of resources any single generation can consume, in which case we must ensure that available resources are justly distributed. Daly redefines efficiency as attaining the greatest level of human welfare from a sustainable flow of throughput (Daly, 1996). Markets can contribute to the efficient allocation of resources, but fail to address sustainability or justice, which take priority over efficiency. GDP fails to accurately measure human welfare, and must be replaced with an indicator that accounts for the costs as well as the benefits of economic activity. Along with John and Clifford Cobb, Daly pioneered the Index of Sustainable Economic Welfare (ISEW), which does exactly this (Daly and Cobb, 1994). While GDP continues to grow, in most countries the ISEW peaked decades ago (Lawn, 2003).

Finally, Daly calls for new rules for the economy. Conventional economists prioritize rules that promote the functioning of competitive free markets and the price mechanism. Daly, in contrast, argues that 'ecological and ethical decisions are price determining, not price determined' (Daly, 1986, p. 321). We must have rules that ensure sustainable scale and just distribution before we can trust in market allocation via the price mechanism. For example, one possible rule for achieving sustainable scale would be to set quantitative limits on throughput from outside the market economy, and let these limits determine prices. One possible rule for achieving just distribution would be to allot everyone an equal share of resources created by society or nature as a whole. Market allocation will only be efficient once these first two rules are satisfied (Daly, 2007).

It's certainly worth noting that conventional economists are often supportive of cap and trade systems, which are one application of Daly's rules. Daly also shares with conventional economists support for policies such as green taxes. The major difference is that conventional economists focus on the Pareto efficiency of these rules in maximizing monetary value, which they generally treat as necessary and sufficient. Daly, in contrast, focuses on the rules' effectiveness in achieving a just, steady-state economy, defined as an economy in which flows of throughput are non-increasing, equitably distributed and within the biophysical carrying capacity of the planet (Daly, 1973, 1991).

We must either achieve a steady-state economy through conscious choice or nature's feedback loops will force it upon us, perhaps catastrophically. Until we change the economic paradigm concerning what is biophysically possible, society will not recognize the need for a steady-state economy. Until we change our goals concerning what is socially, psychologically and morally desirable, society will view a steady state as an unacceptable sacrifice. Until we make our economic institutions more just, sustainable 
and efficient, a steady-state economy is not possible. Daly has laid the groundwork. It is the task of Daly's intellectual and moral heirs to move us forward.

\subsection{ORGANIZATION OF THE BOOK}

The remaining chapters in these volumes provide not only an overview of Herman's foundational work in ecological economics, but also showcase continuing efforts to build a new economic system that is value driven, science based and solutions oriented. The volumes are divided into six parts, including an introduction and conclusions. The middle sections parallel the leverage points for changing complex systems described above: 'Changing the paradigm,' 'Changing the goals' and 'Changing the rules,' with an additional section on the 'Steady-state economy.' There is some overlap between the parts. In the remainder of this overview, we will use chapter to refer to the Edward Elgar edition and article to the online volume.

The second chapter in the Introduction section is by Daly's long-time collaborator and World Bank colleague, Robert Goodland (see the eulogy in the Preface). Goodland provides a superb overview of Herman's lifetime contribution to economics, divided between a brief but excellent synthesis of his theoretical contributions and specific solutions to global problems ranging from ecological degradation to financial instability. The chapter concludes with a reference list with particular emphasis on Daly's earlier works. A chapter by Daly's long-time collaborator, Robert Costanza, describes their efforts over the past 35 years to build a sustainable and desirable future. The online companion volume adds to this an interview with Herman Daly edited by Deepak Malghan.

Part II on 'Changing the paradigm: what is biophysically possible, and how do humans behave?' begins with an online article in by David Batker, one of Daly's former students and the Executive Director of Earth Economics, a non-governmental organization (NGO) dedicated to developing ecological economic solutions to pressing societal problems. Batker's article places Daly's theoretical work in the context of previous revolutions in economics, explaining how new paradigms generate new goals, new institutions to achieve them and new ways to measure their success. The article also explains how Earth Economics has applied this theory to help solve real-life problems. Chapter 4 by Jonathan Harris, a Senior Research Associate and Director of the Theory and Education Program at Tufts University's Global Development and Environment Institute, presents the biophysical evidence supporting the paradigm that the economic system 
is sustained and contained by our finite global ecosystem. He concludes that market forces will not solve the challenges this presents, and calls for an activist macroeconomics that simultaneously achieves both justice and sustainability. Chapter 5 is by Arild Vatn, an institutional economist at the Norwegian University of Life Sciences and former President of the European Society for Ecological Economics. His chapter addresses limits, both those imposed by the biological and physical constraints of our finite planet and those imposed by society. He also addresses social constructions of no-limits, essentially the beliefs that finite resources place no limits on consumption, and that there is no limit to the human desire to consume. This provides a nice segue to Chapters 6 and 7, which focus on human behavior. Conventional economists have traditionally assumed that people are rational and primarily motivated by self-interest. Chapter 6 is by John Gowdy, an ecological economist at Rensselaer Polytechnic Institute and former President of the International Society for Ecological Economics. Gowdy's chapter explores how behavioral economics, evolutionary psychology and neuroscience have changed our understanding of human behavior, with profound implications for conventional economic models and public policy. He concludes that different economic institutions can stimulate or inhibit humanity's innate propensity for the cooperative behavior required to manage biophysical constraints, and that markets may inhibit such behavior. The concluding chapter in Part II (reprinted as an article in the online edition) is by William Rees, Professor Emeritus of City and Regional Planning at the University of British Columbia, developer of ecological footprint analysis and winner of the Blue Planet Prize. Rees applies insights from the evolutionary biology of human cognition to understand why conventional economists and policy makers have largely rejected Daly's worldview of the economy as sustained and contained by a finite global ecosystem. He concludes that new information and rational argument rarely undermine deeply held convictions. Getting people to accept the dramatic changes needed to confront ecological overshoot will require 'a world program of social re-engineering. . .to assert humanity's collective intelligence and reason over people's predisposition to defend the status quo.'

Part III on 'Changing the goals: what is socially, psychologically and ethically desirable?' explores the goals of sustainable scale, just distribution and efficient allocation. Chapter 8 by Philip Lawn, Professor of Ecological Economics at Flinders University, Australia, explains the importance of these goals and the order in which they should be addressed. Arguing that distribution becomes increasingly important on a full planet and has too often been neglected in theory and practice, he proposes several policies for achieving an equitable distribution of resources within and between 
nations. An article by Gary Flomenhoft, former lecturer and research associate at the University of Vermont now doing his doctoral work at the University of Queenland, Australia, also focuses on just distribution. Gary explains how the adoption of Pareto efficiency as the central goal of conventional economics led the discipline to largely ignore problems with distribution, and documents how inequality has exploded in recent years. He then suggests a number of policies for addressing both inequality and poverty. Chapter 9 by Salah El Serafy, a former senior economist and colleague of Herman Daly and Robert Goodland at the World Bank, focuses on measuring real income, defined as the maximum amount one can consume over some time period and still be as well off at the end as at the beginning. He explores the implications of this definition for national income accounts, capital stocks (including natural capital), the steady-state economy and the purpose of economic activity. An article by Mathis Wackernagel, co-developer with Rees of the ecological footprint, co-recipient of the Blue Planet Prize and Director of the Global Ecological Footprint Network, provides a brief overview of the organization's annual report, which was dedicated to Herman Daly. The report adopts sustainability and justice as fundamental goals: the global footprint currently exceeds global productive capacity, which is unsustainable, and many nations currently exceed their national productive capacity, imposing ecological costs on others, which is unjust.

Part IV turns to 'Changing the rules: institutions for a sustainable and desirable future.' Chapter 10 by Clifford Cobb, co-developer of the Index of Sustainable Economic Welfare and the Genuine Progress Indicator, focuses on shifting taxes from earned to unearned income, particularly that generated by land and other natural resources, as a policy that simultaneously promotes a more just, efficient and sustainable allocation of resources. An article by Lester Brown, founder of World Watch, founder and President of the Earth Policy Insitute and world-renowned environmental analyst, focuses on shifting subsidies from taxes onto activities that harm the environment. The bumper sticker summaries of these two chapters are 'tax what we take, not what we make' and 'tax bads, not goods.' Chapter 11 by John Cobb, co-author with Herman Daly of For the Common Good, global authority on Whiteheadian Process Thought and theologian at Claremont University, focuses on the monetary system. Specifically, Cobb shows that modern monetary systems based on interest bearing debt demand never-ending economic growth to avoid financial collapse, which is impossible on a finite planet. He proposes instead a 100 percent fractional reserve system and decentralization of the monetary system, both fundamental changes in one of the economy's most important institutions. An article by Sabine O'Hara, current President of the 
International Society for Ecological Economics and Dean of the College of Agriculture, Urban Sustainability and Environmental Sciences at the University of the District of Columbia, concludes the section with an article on production in the context of the biophysical and social processes required to sustain it. She explains why a theory of economic production must expand its boundaries to account for these contextual processes, and offers a policy agenda for ensuring their maintenance.

Part V turns to one specific institution that is a prerequisite for avoiding ecological collapse: 'The steady-state economy.' This section is similar in both the online and Edward Elgar editions, but the chapters in the latter have been significantly updated. Peter Victor, Professor at York University and recent recipient of the Boulding Award, initiates Part V with a detailed history of the steady-state economy in economic thought, followed by a brief overview of his simulation models that show how such an economy could plausibly be achieved in both the United States and Canada. Joan Martinez-Alier, Professor at the Autonomous University of Barcelona and founding member and former President of the ISEE addresses the need for degrowth en route to a steady-state economy. For degrowth to be socially sustainable, the richest economies will have to shrink enough that the poorest countries can still expand without exceeding environmental constraints. After discussing degrowth in the context of the financial crisis, oil prices, carbon dioxide $\left(\mathrm{CO}_{2}\right)$ emissions and social and political movements from the south, he concludes that we can only transition to a steady-state economy if we change our economic goals to emphasize a good life (buen vivir) rather than materialistic consumption as measured by GDP. The online version was written shortly after the ongoing 2007-08 financial crisis, while the book chapter updates this to 2014. Brian Czech, founder and President of the Center for the Advancement of a Steady State Economy (www.Steadystate.org), Professor of Ecological Economics at Virginia Tech and wildlife biologist, concludes this section by tackling the politics of a steady-state economy. He describes several problems that impede political support for the steady state, and argues that one important step to overcoming the obstacles is to document widespread support for such an economy by leading academic societies. He describes his own increasingly successful efforts to generate and document such support.

After identifying the leverage points for changing complex systems, Meadows adds that the most powerful lever is to transcend the paradigm, never allowing ourselves to become too bound to a particular preanalytic vision. It is therefore fitting that both volumes conclude with a chapter by Peter Brown, Professor at McGill University, that presents ecological economics as only a partial step on the path to a sustainable and desirable future. To complete its journey, ecological economics must adopt a new 
system of ethics that extends moral standing to life as a whole, explicitly recognizing that humans are simply one subset of citizens in the grander ecological community.

Together, these volumes explain the origins of some of the most serious threats currently faced by human society, and offer concrete suggestions for solving them. We hope the economic theory presented here can help transform the economic system.

\section{NOTES}

1. It is important to note that both flow thresholds and stock thresholds exist. Using the example of greenhouse gases (GHGs), we exceed a threshold when the stock of GHGs results in an unacceptable degree of climate change, for example, one that causes positive feedback loops of rising methane emissions or falling albedo. We exceed a flow threshold when the emission of GHGs exceeds the capacity of ecosystems to absorb them and they accumulate into an ever-growing stock. Unfortunately, it may be impossible to accurately predict precisely where a threshold lies. Furthermore, given the frequent time lags between cause and effect in complex ecosystems, we may not suffer the impacts of crossing a threshold until decades into the future.

2. Conventional or mainstream economics in this chapter refers to neoclassical economics, or more specifically to the belief that the goal of economic activity at any point in time is the satisfaction of subjective individual preferences, which in a market economy leads to an equilibrium that balances supply with demand across all goods and services in an economy and maximizes economic surplus, typically measured in monetary terms. People are generally considered insatiable, so the goal over time is continuous economic growth. However, the worldview that the economy is the whole and the ecosystem the part permeates many heterodox schools of economic thought as well.

3. A growing number of economists recognize that GDP is a poor measure of economic welfare (Stiglitz et al., 2009; van den Bergh, 2009), which only makes mainstream economics' continued obsession with the metric more puzzling.

\section{REFERENCES}

Alvaredo, F., A.B. Atkinson, T. Piketty and E. Saez (2013). The top 1 percent in international and historical perspective. Journal of Economic Perspectives 27, 3-20.

Ayres, R.U. and A.V. Kneese (1969). Production, consumption, and externalities. American Economic Review 59 (3), 282-97.

Ayres, R.U., J.C.J.M. van den Bergh, D. Lindenberger and B. Warr (2013). The underestimated contribution of energy to economic growth. Structural Change and Economic Dynamics 27, 79-88.

Barnett, H. and C. Morse (1963). Scarcity and Growth: The Economics of Natural Resource Availability. Baltimore, MD: Johns Hopkins University Press.

Beckerman, W. (1972). Economists, scientists, and environmental catastrophe. Oxford Economic Papers 24, 327-44.

Brown, L. (2012). Full Planet, Empty Plate: The New Geopolitics of Food Scarcity. Washington, DC: Earth Policy Institute. 
Cipriani, G.P., D. Lubian and A. Zago (2009). Natural born economists? Journal of Economic Psychology 30, 455-68.

Clark, J.B. (1908). The Distribution of Wealth: A Theory of Wages, Interest and Profits. New York: The Macmillan Company.

Crutzen, P. (2002). Geology of mankind. Nature 415, 23.

Daly, H.E. (1968). On economics as a life science. Journal of Political Economy 76, 392-406.

Daly, H.E. (1973). Toward a Steady-state Economy. San Francisco, CA: W.H. Freeman and Co.

Daly, H.E. (1977). Steady-state Economics: The Political Economy of Bio-physical Equilibrium and Moral Growth. San Francisco, CA: W.H. Freeman and Co.

Daly, H.E. (1986). Thermodynamic and economic concepts as related to resourceuse policies: comment. Land Economics 62, 319-22.

Daly, H.E. (1991). Steady State Economics: 2nd Edition with New Essays. Washington, DC: Island Press.

Daly, H.E. (1992). Allocation, distribution, and scale: towards an economics that is efficient, just, and sustainable. Ecological Economics 6, 185-93.

Daly, H.E. (1996). Beyond Growth: The Economics of Sustainable Development. Boston, MA: Beacon Press.

Daly, H.E. (1997). Georgescu-Roegen versus Solow/Stiglitz. Ecological Economics 22, 261-6.

Daly, H.E. (2007). Ecological Economics and Sustainable Development, Selected Essays of Herman Daly. Cheltenham, UK and Northampton, MA, USA: Edward Elgar Publishing.

Daly, H.E. and J.B. Cobb, Jr (1994). For the Common Good: Redirecting the Economy Toward Community, the Environment, and a Sustainable Future (2nd edn). Boston, MA: Beacon Press.

Dasgupta, P. (2008). Nature in economics. Environmental and Resource Economics 39, 1-7.

Dasgupta, P.S. and G.M. Heal (1979). Economic Theory and Exhaustible Resources. Cambridge: Cambridge University Press.

Farley, J., A. Schmitt Filho, M. Burke and M. Farr (2015). Extending market allocation to ecosystem services: moral and practical implications on a full and unequal planet. Ecological Economics 117, 244-52.

Foley, J.A., N. Ramankutty, K.A. Brauman et al. (2011). Solutions for a cultivated planet. Nature 478, 337-42.

Godfray, H.C.J., J.R. Beddington, I.R. Crute et al. (2010). Food security: the challenge of feeding 9 billion people. Science 327, 812-18.

Hartwick, J.M. (1977). Intergenerational equity and the investment of rents from exhaustible resources. American Economic Review 67 (5), 972-4.

IPCC (2013). Climate Change 2013. The Physical Science Basis Summary for Policymakers. United Nations, available at http://www.ipcc.ch/ (accessed 16 December 2015).

Kaysen, C. (1972). The computer that printed out $\mathrm{W}^{*} \mathrm{O} * \mathrm{~L}^{*} \mathrm{~F}^{*}$. Foreign Affairs 50, 660-68.

Kirchgässner, G. (2005). (Why) are economists different? European Journal of Political Economy 21, 543-62.

Krutilla, J. (1967). Conservation reconsidered. American Economic Review 57, 777-86.

Lawn, P.A. (2003). A theoretical foundation to support the Index of Sustainable 
Economic Welfare (ISEW), Genuine Progress Indicator (GPI), and other related indexes. Ecological Economics 44, 105-18.

Lucas, R.E., Jr (2004). The Industrial Revolution: Past and Future. 2003 Annual Report Essay. The Region, Federal Reserve Bank of Minneapolis, https://www. minneapolisfed.org/publications/the-region/the-industrial-revolution-past-andfuture (accessed 16 December 2015).

Malghan, D. (2011). A dimensionally consistent aggregation framework for biophysical metrics. Ecological Economics 70, 900-909.

Marshall, A. (1890). Principles of Economics. New York: The Macmillan Company.

Meadows, D. (2009). Leverage points: places to intervene in a system. Solutions $\mathbf{1}$, 41-9.

Meadows, D.H., D.L. Meadows, J. Randers and W. Behrens (1972). The Limits to Growth: A Report for the Club of Rome's Project on the Predicament of Mankind. New York: Universe Books.

Millennium Ecosystem Assessment (2005). Ecosystems and Human Well-being: Synthesis. Washington, DC: Island Press.

Milliman, J.W. (1962). Can people be trusted with natural resources? Land Economics 38, 199-218.

Nordhaus, W.D., H. Houthakker and R. Solow (1973). The allocation of energy resources. Brookings Papers on Economic Activity, 529-76.

Okun, A.M. (1975). Equality and Efficiency: The Big Tradeoff. Washington, DC: Brookings Institution Press.

Passell, P., M. Roberts and L. Ross (1972). Review of 'The Limits to Growth'. New York Times Book Review, 2 April, Section 7, 1, 10, 12-13.

Piketty, T. (2014). Capital in the 21 st Century. Cambridge, MA: Harvard University Press.

Piketty, T. and E. Saez (2006). The evolution of top incomes: a historical and international perspective. American Economic Review 96, 200-205.

Posner, R.A. (1985). Wealth maximization revisited. Notre Dame Journal of Law, Ethics and Public Policy 2, 85-105.

Reid, W.V., D. Chen, L. Goldfarb et al. (2010). Earth system science for global sustainability: grand challenges. Science 330, 916-17.

Richerson, P.J., R. Boyd and R.L. Bettinger (2001). Was agriculture impossible during the Pleistocene but mandatory during the Holocene? A climate change hypothesis. American Antiquity 66, 387-411.

Rockstrom, J., W. Steffen, K. Noone et al. (2009). A safe operating space for humanity. Nature 461, 472-5.

Simpson, R.D., M.A. Toman and R.U. Ayres (2005). Scarcity and Growth Revisited: Natural Resources and the Environment in the New Millenium. Washington, DC: Resources for the Future.

Smith, K.V. and J. Krutilla (1979). Scarcity and Growth Reconsidered. Baltimore, MD: Johns Hopkins University Press.

Solow, R.M. (1973). Is the end of the world at hand? Challenge 16, 39-50.

Solow, R.M. (1974a). Intergenerational equity and exhaustible resources. Review of Economic Studies 41, 29-45.

Solow, R.M. (1974b). What do we owe to the future? Nebraska Journal of Economics and Business 13, 3-16.

Solow, R.M. (1997). Georgescu-Roegen versus Solow-Stiglitz. Ecological Economics 22, 267-8. 
Spengler, J. (1961). Natural Resources and Economic Growth. Washington, DC: Resources for the Future.

Steffen, W., J. Grinevald, P. Crutzen and J. McNeill (2011). The Anthropocene: conceptual and historical perspectives. Philosophical Transactions of the Royal Society A: Mathematical, Physical and Engineering Sciences 369, 842-67.

Stern, N. (2006). Stern Review: The Economics of Climate Change. Cambridge: Cambridge University Press.

Stigler, G.J. and G.S. Becker (1977). De Gustibus Non Est Disputandum. American Economic Review 67, 76-90.

Stiglitz, J.E. (1974). Growth with exhaustible natural resources: efficient and optimal growth paths. Review of Economic Studies 41, 123-37.

Stiglitz, J.E. (1997). Georgescu-Roegen versus Solow/Stiglitz. Ecological Economics 22, 269-70.

Stiglitz, J.E. (2014). Inequality is not inevitable. New York Times, 27 June.

Stiglitz, J.E., A. Sen, J.-P. Fitoussi et al. (2009). Report by the Commission on the Measurement of Economic Performance and Social Progress, available at http:// www.stiglitz-sen-fitoussi.fr/en/documents.htm (accessed 16 December 2015).

The President's Materials Policy Commission (1952). Resources for Freedom: A Report to the President. Volume I: Foundations for Growth and Security. Washington, DC: United States Government Printing Office.

Tilman, D., C. Balzer, J. Hill and B.L. Befort (2011). Global food demand and the sustainable intensification of agriculture. Proceedings of the National Academy of Sciences 108, 20260-64.

van den Bergh, J. (2001). Ecological economics: themes, approaches, and differences with environmental economics. Regional Environmental Change 2, 13-23.

van den Bergh, J.C.J.M. (2009). The GDP paradox. Journal of Economic Psychology 30, 117-35.

Yissar, R. (2013). Neoclassical economic theory and the question of environmental limits to growth, 1950-1975. Master's thesis, Porter School of Environmental Studies, Tel Aviv University. 